\title{
\begin{tabular}{l|l} 
Mitraries & DSpace@MIT
\end{tabular}
}

\author{
MIT Open Access Articles
}

(Why) Should Current Account Balances Be Reduced?

The MIT Faculty has made this article openly available. Please share how this access benefits you. Your story matters.

Citation: Blanchard, Olivier, and Gian Maria Milesi-Ferretti. “(Why) Should Current Account Balances Be Reduced?" IMF Economic Review 60.1 (2012): 139-150.

As Published: http://dx.doi.org/10.1057/imfer.2012.2

Publisher: Palgrave Macmillan

Persistent URL: http://hdl.handle.net/1721.1/78848

Version: Author's final manuscript: final author's manuscript post peer review, without publisher's formatting or copy editing

Terms of use: Creative Commons Attribution-Noncommercial-Share Alike 3.0 
March 1, 2011 SDN/11/03

\section{(Why) Should Current Account Balances Be Reduced?}

Olivier Blanchard and Gian Maria Milesi-Ferretti 


\section{INTERNATIONAL MONETARY FUND}

Research Department

\section{(Why) Should Current Account Balances Be Reduced?}

Prepared by Olivier Blanchard and Gian Maria Milesi-Ferretti ${ }^{1}$

Authorized for distribution by Olivier Blanchard

March 1, 2011

DISCLAIMER: This Staff Discussion Note represents the views of the authors and does not necessarily represent IMF views or IMF policy. The views expressed herein should be attributed to the authors and not to the IMF, its Executive Board, or its management. Staff Discussion Notes are published to elicit comments and to further debate.

JEL Classification Numbers: E21, E22, F32, F33, F36, F41

Keywords:

global imbalances; current account; exchange rates

Authors’ E-mail Addresses: oblanchard@imf.org; gmilesiferretti@imf.org

\footnotetext{
${ }^{1}$ We are grateful to George Akerlof, Caroline Atkinson, Tam Bayoumi, Ricardo Caballero, Stijn Claessens, Jörg Decressin, Nicolas Eyzaguirre, Josh Felman, Jean Pierre Landau, Reza Moghadam, Antonio Spilimbergo, Ted Truman, Kenichi Ueda, and David Vines for useful comments.
} 


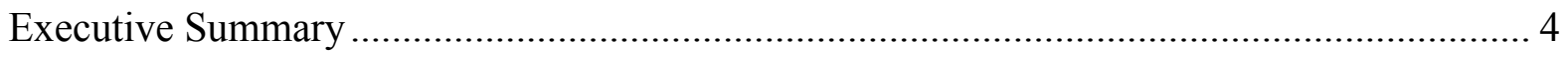

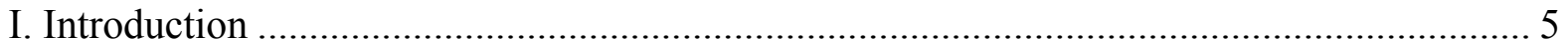

II. Why Might a Country Want to Reduce Its Current Account Deficit or Surplus ................ 5

A. Current Account Deficits: Possibly Unwise, and Unsustainable.................................. 5

B. Current Account Surpluses: Possibly Unwise, but Largely Sustainable........................ 6

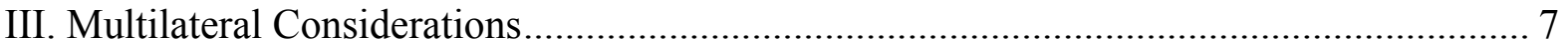

A. Current Account Deficits, Sudden Stops, and Spillover Effects.................................. 7

B. Export-Led Growth, Current Account Surpluses, and Unfair Competition.................... 8

C. Current Account Surpluses, the Liquidity Trap, and World Demand........................... 9

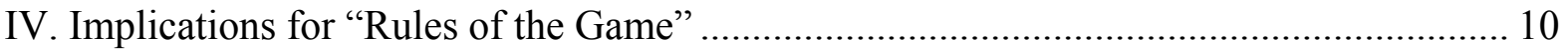

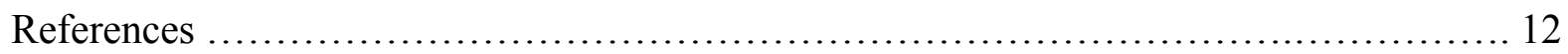

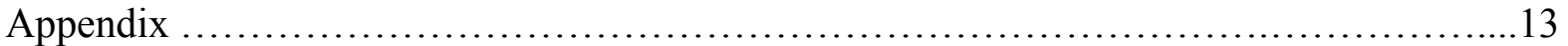

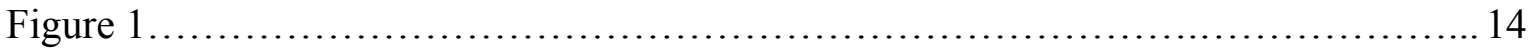

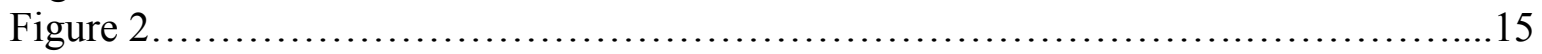

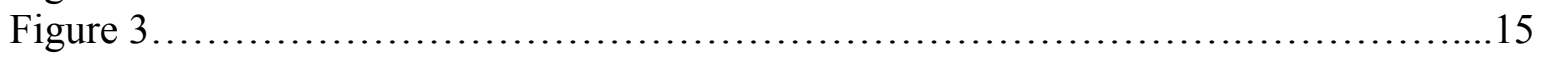




\section{EXECUTIVE SUMMARY}

The purpose of this note is to discuss two complex issues. First, why might a country want to reduce its current account deficit or surplus? And second, why might the international community ask for more? Answers to these questions are needed to inform the design of "rules of the game" that countries should abide by, and address the G-20's request to the IMF to help develop "indicative guidelines" for the reduction of global current account imbalances.

In general, there are both domestic and multilateral reasons for countries to reduce current account deficits and surpluses. In many cases, current account balances reflect underlying domestic distortions. It is then in the interest of the country to remove those distortions and, in the process, reduce imbalances (Blanchard and Milesi-Ferretti, 2010). We identify three instances in which the case for reducing imbalances rests on multilateral considerations:

- Worries about cross-border effects of sudden stops justify multilateral surveillance. They also suggest, however, looking beyond the current account deficit, at the whole structure of the capital account.

- Worries about unfair competitive advantage may justify restrictions on undervaluation and current account surpluses, but implementation is likely to be difficult. Proving intent - namely, that surpluses reflect a deliberate strategy designed to gain competitive advantage-is likely to be difficult. Ignoring intent may be unfair.

- $\quad$ Worries about global demand if part of the world economy is in a liquidity trap. In that context, smaller current account surpluses in surplus countries might actually benefit growth in the rest of the world.

The relevant question is why surplus countries should oblige. A pragmatic argument is that in many (but not all) surplus countries domestic and multilateral considerations actually go in the same direction. To the extent that these countries reduce domestic distortions, this will be good for them, and good for the rest of the world. And, even if one could hope for more, this can go a long way toward strengthening the world recovery. 


\section{INTRODUCTION}

This Staff Discussion Note — a sequel to Blanchard and Milesi-Ferretti (2010)—was inspired by the G-20's request to the IMF to help develop "indicative guidelines" for the reduction of global current account imbalances. Its purpose is to discuss two complex issues. First, why might a country want to reduce its current account deficit or surplus? And second, why might the international community ask for more? Answers to these questions are needed to inform the design of "rules of the game" that countries should abide by, and contribute to the development of corresponding "indicative guidelines."

Given the focus of this paper, we limit our discussion of the immense literature on imbalances to a few indicative references, without any claim of completeness. For a timeline of global imbalances, an assessment of their prospects, as well as our interpretation of their driving factors, we refer the reader to our earlier work.

This Staff Discussion Note is organized as follows. Section II discusses "domestic" reasons why countries may want to reduce current account deficits and surpluses. Section III focuses on multilateral considerations for reducing external imbalances. In the concluding section IV we look at the case for establishing "rules of the game."

\section{Why Might a Country Want to Reduce Its CurRent Account Deficit or SURPLUS}

This issue is discussed in more detailed in our earlier work (Blanchard and Milesi-Ferretti, 2010), and we therefore cover it here succinctly.

\section{A. Current Account Deficits: Possibly Unwise, and Unsustainable}

Deficits can arise for "bad" or "good" reasons.

Deficits can arise for bad reasons: examples are financial regulation failures fueling credit booms, and misbehavior of fiscal authorities reducing national saving. If this is the case, correcting these distortions is generally desirable, and will lead to a reduction in the deficit (killing two birds with one stone). ${ }^{2}$

Deficits can also arise for good reasons: temporarily low export prices or bright future economic prospects, leading to low saving; or high marginal product of capital, leading to high investment. But, even in that case, there are still two reasons why one should worry about them. First, the good reasons may interact with distortions, leading, for example, to a

\footnotetext{
${ }^{2}$ In principle removing some distortions in a second-best world is not necessarily welfare-increasing. In practice, we could not find obvious examples of cases where removing distortions leading to excessive current account deficits or surpluses would be welfare-decreasing.
} 
dynamic Dutch disease. ${ }^{3}$ Or foreign lenders may change their mind, leading to a sudden stop, which will trigger a painful adjustment, more painful than borrowers anticipated or took into account. ${ }^{4}$

\section{B. Current Account Surpluses: Possibly Unwise, but Largely Sustainable}

Surpluses do not typically suffer from the same stigma as deficits. But they can also arise for "bad" or for "good" reasons.

Surpluses can arise for bad reasons: lack of social insurance, driving up private saving; inefficient financial intermediation, leading to low investment; and other distortions. These distortions will typically be reflected in a more depreciated real exchange rate. With domestic distortions, their removal is generally desirable - again, killing two birds with one stone. Distortions can also arise at the supranational level - for example, in the form of insufficient global liquidity provision, leading to high reserve accumulation-but a discussion of these issues goes beyond the scope of this paper. ${ }^{5}$

Surpluses can arise for good reasons: for example an aging population accumulating saving for retirement, or limited investment opportunities at home. They can also arise from externalities, such as positive productivity externalities from a strong tradable sector, leading to an export-led growth strategy characterized by low domestic demand and high exports (although the net benefits of an export-led growth strategy may decrease over time). ${ }^{6}$

Whether they arise for good or bad reasons, individual surpluses, in contrast to deficits, can be sustained for a long time, if not forever. In particular, protracted current account surpluses do not depend on the willingness of foreign investors to finance domestic consumption and investment, and hence are not hostage to changes in investor sentiment. Of course, they naturally and eventually come to an end, as the accumulation of foreign assets increases domestic wealth, increasing demand and reducing the current account surplus. But this is likely to happen gradually, in contrast to sudden stops for current account deficit countries. ${ }^{7}$

To summarize: we have argued that imbalances can, from the point of view of the country itself, be "good" (come from desirable intertemporal choices) or "bad" (reflect underlying distortions). When they are bad, a country would clearly be better off eliminating the underlying distortions and thus reducing the imbalance.

\footnotetext{
${ }^{3}$ See, for example, Caballero and Lorenzoni (2007).

${ }^{4}$ See, for example, Korinek (2010).

${ }^{5}$ We touch on this issue in our previous work. For a more comprehensive discussion of proposals to reform the international financial system, see Mateos y Lago, Duttagupta, and Goyal (2009).

${ }^{6}$ We discuss the potential multilateral consequences of such a strategy in the next section.

${ }^{7}$ Clearly surpluses and deficits at the global level add up to zero. The point here is that individual surpluses can go on for a long time, while individual deficits face the risk of changes in investor sentiment.
} 
But, unless deficits or surpluses have adverse effects, not only for the country itself, but for other countries as well, one may well argue this is ultimately the country's responsibility. Put starkly, one may argue that every country has the right to be wrong, so long as it does not cause harm to others. To go further, and make a case for multilateral surveillance, one must identify these potentially adverse cross-border effects. To this we now turn.

\section{Multilateral Considerations}

Three distinct arguments for cross-border effects can be and have indeed been made, one suggesting a case for restrictions on current account deficits, the other two for restrictions on current account surpluses. We discuss them in turn.

\section{A. Current Account Deficits, Sudden Stops, and Spillover Effects}

As discussed earlier, large current account deficits raise the risk of a sudden stop - and experience has shown that these episodes often lead to large financial disruptions. If, as is the case, cross-border resolution processes are poor (and this is likely to remain the case for some time), then other countries will be affected-all the more so given the extent and complexity of cross-border financial linkages. Indeed, the argument is similar to the one for large financial institutions: large current account deficits - particularly in countries that are large and/or with extensive cross-border financial links - increase systemic risk. Individual countries will typically not take this fully into account, and there is therefore a role for prudential measures.

The argument is surely valid. It was indeed central to the precrisis analysis at the IMF of the risks posed by global imbalances. Specifically, this analysis emphasized the high costs that would be associated with a "disorderly adjustment" of imbalances, featuring a rapid and sharp depreciation of the U.S. dollar, balance sheet effects, protectionist pressures, higher interest rates and risk premiums, and output declines (IMF, 2007). Even if the crisis took a very different form, the worries were perfectly justified.

However, the argument suggests that surveillance - and possibly restrictions - should focus on a broader number of indicators than solely the current account balance. For example, cross-border effects are likely to depend not only on net flows, but also on gross flows. They are likely to depend not only on flows, but on stocks, on the level and composition of foreign assets and liabilities, the distribution of external exposures across sectors, and on the size of the country. ${ }^{8}$

\footnotetext{
${ }^{8}$ In the recent crisis, for example, the evidence points to high precrisis short-term debt as having been particularly costly in terms of output for emerging markets (Blanchard, Das, and Faruqee, 2010). In a sample that includes both advanced countries and emerging markets, the evidence points to large precrisis current account deficits being associated with large output and demand declines (Lane and Milesi-Ferretti, 2010).
} 


\section{B. Export-Led Growth, Current Account Surpluses, and Unfair Competition}

An export-led growth strategy - that is, a policy combination of a depreciated real exchange rate and enforced low domestic demand (through high saving and/or low investment) - is formally equivalent to a combination of tariffs on imports cum subsidies on exports, and low domestic demand to maintain internal balance. This second, equivalent combination is illegal under the World Trade Organization. Should the first one be as well?

One may argue that the first and second combinations potentially differ in their intent. A country that, for whatever reasons (say, poor social insurance, or adverse demographics), has a high saving rate and/or a low investment rate requires a depreciated exchange rate to maintain internal balance. The undervalued exchange rate is then the result of other factors, not of a deliberate policy of undervaluation. In contrast, a country that imposes tariffs and subsidies (and then decreases domestic demand to maintain internal balance) is directly targeting an improvement in competitiveness. But in practice, proving intent or lack thereof may be very difficult.

Can one think of telltale signs? In particular, can the steady accumulation of reserves beyond any reasonable precautionary level be interpreted as intentional undervaluation? Not necessarily, at least in theory. If a country running a large current account surplus has in addition capital controls on purchases of foreign assets by domestic residents, foreign asset accumulation will take the form of accumulation of reserves by the central bank. The simultaneous removal of capital controls and no further reserve accumulation could result in roughly the same exchange rate, with the private sector accumulating significant net foreign assets. In this case, the source of the depreciated exchange rate is not currency manipulation, but the underlying saving/investment balance.

To summarize, there is a reasonable argument for revisiting whether, from a multilateral viewpoint, countries should be allowed to pursue export-led growth strategies; even if such a strategy allows them to catch up more quickly, this happens partially at the expense of other countries. As long as these countries were small in economic terms, the issue could be avoided, but this is no longer the case. The practical issue is that, while an export-led growth strategy is likely to show up in a large current account surplus, a current account surplus is no proof of a deliberate export-led growth strategy. Proving intent - namely, that surpluses reflect a deliberate strategy designed to gain competitive advantage - is likely to be difficult. Ignoring intent may be politically unacceptable. ${ }^{9}$

\footnotetext{
${ }^{9}$ The complexity of the issue is reflected in Article IV of the Fund's Articles which sets out obligations for members respecting their exchange rate policies. For the purposes of these obligations, the concept of an "exchange rate policy" is broad and includes domestic policies (e.g., interest rate policies) that are pursued for balance of payments purposes. In some cases, these obligations focus on the intent of countries in implementing their exchange rate policies. For example, Article IV, Section 1 (iii) prohibits countries from manipulating exchange rates "in order to gain an unfair competitive advantage over other members." In other cases, Article IV focuses on the results of these policies. Thus, the 2007 Surveillance Decision (which sets out guidance to members for the purposes of Article IV) provides that members should avoid exchange rate policies that result in "external instability" - for example, in the form of a significantly undervalued or overvalued exchange rate ("fundamentally misaligned").
} 


\section{Current Account Surpluses, the Liquidity Trap, and World Demand}

The third argument that has been advanced is that, when part of the world economy is in a liquidity trap, a larger current account surplus in a given country reduces demand and output in other countries and thus affects them adversely.

The argument is logically well founded. It is important, however, to understand its scope and its limits.

To do so, it is useful to start with a discussion of the issue in normal times, that is, when interest rates are positive throughout the world. In that case, the argument just does not carry: Countries can run surpluses or deficits without necessarily affecting output in other countries, because interest rates and exchange rates can be adjusted to maintain output at potential in all countries.

Indeed, if central banks target stable inflation, the adjustment of interest rates and the implied exchange rate adjustments will take place naturally.

Suppose that a country wants to increase its saving rate. To counteract the decrease in domestic demand and avoid a decline in output, the central bank will reduce the interest rate, leading to exchange rate depreciation and an improvement in the current account. Faced with an exchange rate appreciation and thus a deterioration of their current account, central banks in the rest of the world will then decrease interest rates so as to maintain their output at potential. The global outcome will be a decrease in interest rates across the world, an exchange rate depreciation and a larger current account surplus of the original country vis-àvis the rest of the world. Output will remain at potential, both in the original country and in the rest of the world. (The appendix provides a simple formalization of this argument and of the arguments below.)

One may argue, however, that the end result is still a larger current account deficit in the rest of the world and that, as we have seen earlier, large current account deficits can prove dangerous. The argument only goes so far: first, even a large surplus in a large country can be offset by small current account deficits across all countries in the rest of the world. Second, and more important empirically, major deficit countries have surely not been "forced" to make the policy and behavioral choices that have resulted in large deficits. ${ }^{10} \mathrm{Had}$ they not made those choices, both current account surpluses and deficits would have been smaller.

Along related lines, one might also argue that if large desired current account surpluses in many countries lead to low interest rates in other countries, this may in turn encourage risk taking and lead to financial excesses in those countries. This mechanism plays an important role in some interpretations of the recent financial crisis that see global imbalances as a key causal factor: large surpluses led to low interest rates, which in turn led to excessive risk

${ }^{10}$ See, for example, Obstfeld and Rogoff (2010). 
taking. This argument again only goes so far: prudential measures in deficit countries would have been and are the appropriate policy response to domestic financial excesses, rather than reductions in current account balances in surplus countries (see the discussion in Bernanke, Bertaut, Pounder DeMarco, and Kamin, 2011).

The argument on the negative multilateral repercussions of large desired current account surpluses becomes stronger, however, when interest rates cannot decrease in the rest of the world. When countries are in a liquidity trap — as is arguably the case today in several large advanced economies - the interest rate cannot decrease if desired global saving rises. In this case, large current account surpluses in some countries can lead to low aggregate demand and lower output in other countries. In principle, these countries could use fiscal policy to sustain domestic demand; but in current circumstances the room for expansionary fiscal policy is severely curtailed by debt sustainability concerns. Thus a decrease in current account surpluses in surplus countries, through a combination of real exchange rate appreciation and higher domestic demand, can lead to higher output in current account deficit countries.

Given current circumstances, we see this as a convincing argument for multilateral guidelines on current account surplus countries. But it should be clear that the argument is time- and country-specific. It would lose relevance in a world in which the equilibrium interest rate for advanced economies (those for which liquidity-trap considerations are currently relevant) became positive, the case we expect to prevail in the not too distant future.

\section{IMPLICATIONS FOR "RULES OF THE GAME"}

The arguments sketched in the previous sections suggest that there are both domestic and multilateral reasons for countries to reduce current account deficits and surpluses under certain circumstances.

We have argued that, in many cases, current account balances reflect underlying domestic distortions. It is then in the interest of the country to remove those distortions and, in the process, reduce imbalances. This part is clear. The more difficult issue is why this should be the subject of multilateral discussions or surveillance. We can think of a few arguments. Domestic obstacles to the adoption of these policies come from several angles, from differences in the assessment of costs and benefits (particularly if the adjustment process can entail short-term costs and long-term benefits) to political economy considerations. ${ }^{11}$ One may then think of a multilateral surveillance process as playing two potentially useful roles: first, as a useful discussion of the differences in assessments; second, and perhaps more relevant, as a potentially useful commitment device for countries to implement some of the required but politically unpalatable fiscal or structural adjustments (this last argument is

\footnotetext{
${ }^{11}$ We have been struck not only by the importance of differences in objective functions, but also by the relevance of differences of opinion about macroeconomic mechanisms across G-20 members in the G-20 Mutual Assessment Process.
} 
clearly one of the main motivations behind the proposals for multilateral rules for fiscal policy within the euro area and the European Union).

We have then examined the case where spillover effects, either from deficits or surpluses, suggest a direct role for multilateral surveillance. We have argued that:

- Worries about cross-border effects of sudden stops justify multilateral surveillance. They also suggest, however, looking beyond the current account deficit, at the whole structure of the capital account.

- $\quad$ Worries about unfair competitive advantage may justify restrictions on undervaluation and current account surpluses, but implementation is likely to be difficult. Proving intent may be next to impossible. Ignoring intent may be unfair.

- Worries about global demand if part of the world economy is in a liquidity trap. In that context, smaller current account surpluses in surplus countries might actually benefit growth in the rest of the world. The relevant question is why surplus countries should oblige. One answer is based on a repeated-game argument: a surplus country today may be a deficit country in the future, and thus benefit from such a rule. The argument is not convincing: the world economy is not ergodic, and the likelihood that the roles will be reversed in the future is small. Another, more pragmatic, argument is that in many (but not all) surplus countries domestic and multilateral considerations actually go in the same direction. To the extent that these countries reduce domestic distortions, this will be good for them, and good for the rest of the world. And, even if one could hope for more, this can go a long way toward strengthening the world recovery. 


\section{References}

Bernanke, Ben S., Carol Bertaut, Laurie Pounder deMarco, and Steven Kamin, 2011, "International Capital Flows and the Returns to Safe Assets in the United States, 20003-2007," Federal Reserve Board International Finance Discussion Paper 1014, February.

Blanchard, Olivier, Mitali Das, and Hamid Faruqee, 2010, "The Initial Impact of the Crisis on Emerging Market Countries," Brookings Papers on Economic Activity, Spring, pp. 263-307.

Blanchard, Olivier, and Gian Maria Milesi-Ferretti, 2010), "Global Imbalances: In Midstream?" in Reconstructing the World Economy, edited by Olivier Blanchard and Il SaKong (Washington: International Monetary Fund).

Caballero, Ricardo, and Guido Lorenzoni, 2007, "Persistent Appreciations and Overshooting: A Normative Analysis,” NBER Working Paper 13077 (Cambridge, MA: National Bureau of Economic Research).

International Monetary Fund, 2007, "Staff Report on the Multilateral Consultation on Global Imbalances with China, the Euro Area, Japan, Saudi Arabia, and the United States," http://www.imf.org/external/np/pp/2007/eng/062907.pdf.

Korinek, Anton, 2010, "Regulating Capital Flows to Emerging Markets: An Externality View," unpublished, University of Maryland, May.

Lane, Philip R., and Gian Maria Milesi-Ferretti, 2010, "The Cross-Country Incidence of the Global Crisis," IMF Working Paper 10/171 (Washington: International Monetary Fund; forthcoming, IMF Economic Review).

Mateos y Lago, Isabelle, Rupa Duttagupta, and Rishi Goyal, 2009, "The Debate on the International Monetary System," IMF Staff Position Note 09/26 (Washington: International Monetary Fund).

Obstfeld, Maurice, and Kenneth Rogoff, 2010, "Global Imbalances and the Financial Crisis: Products of Common Causes," in Asia Economic Policy Conference Volume, Federal Reserve Bank of San Francisco. 


\section{Appendix}

\section{Current Account Surpluses, the Liquidity Trap, and World Demand. A Simple Model.}

Consider the following simple two-country macroeconomic model. Demand for domestic output $Y$ in the home country is a function of the real exchange rate $e$ (the price of domestic goods in terms of foreign goods), with an appreciation reducing demand by crowding out net exports, and of the interest rate $r$, with a lower interest rate associated with higher demand. An analogous condition holds in the foreign country, where instead an appreciation in the home country is associated with higher output.

$$
\begin{array}{lr}
Y=Y(e, r) \quad Y_{e}<0, Y_{r}<0 \\
Y^{*}=Y^{*}\left(e, r^{*}\right) & Y_{e}^{*}>0, Y_{r^{*}}^{*}<0
\end{array}
$$

Iso-output loci for the home and foreign country are represented in Figure 1. For the home country, for a given level of output, a decrease in the interest rate (which increases domestic demand) requires an appreciation (which reduces the current account): the domestic isooutput loci are downward sloping. Symmetrically, the foreign iso-output loci are upward sloping.

Assume that policy is used to maintain output at potential in both countries. And assume perfect capital mobility, so domestic and foreign interest rates must be equal: ${ }^{12}$

$$
\begin{aligned}
& Y=\bar{Y} \\
& Y^{*}=\bar{Y}^{*} \\
& r=r^{*}
\end{aligned}
$$

The two corresponding iso-loci are drawn in Figure 2, and equilibrium is given by point $\mathrm{A}$. Now consider an increase in desired saving in the foreign country. For a given $r^{*}$, maintaining output at potential requires a depreciation from the point of view of the foreign country, so, given our definition of the exchange rate, an increase in $e$. The right shift in the foreign iso-output curve implies that the equilibrium is now at $\mathrm{B}$. The exchange rate is higher and the equilibrium interest rate is lower. The increase in saving in the foreign country drives down the world interest rate. In the foreign country, the adverse shift in demand is offset by a lower interest rate and a depreciation. Output remains at potential, and the current account improves. In the home country, the effect of the appreciation is offset by the lower interest rate and output remains at potential. The appreciation leads to a deterioration of the current account.

\footnotetext{
${ }^{12}$ It is straightforward to include a risk premium in the model driving a wedge between the domestic and foreign interest rates.
} 
Now consider the case in which the desired increase in foreign saving occurs when the domestic short-term interest rate is at or close to zero. In Figure 3, the initial iso-loci are drawn so the initial equilibrium interest rate is equal to zero.

In response to an increase in desired saving in the foreign country, the foreign iso-locus shifts to the right. But now that the interest rate can no longer decrease, the new equilibrium is at point $\mathrm{C}$. The home country cannot offset the depreciation through a decrease in the interest rate and thus output is lower. (The iso-locus going through point $\mathrm{C}$ corresponds to a lower level of output.) Thus, in this case, higher desired saving in the foreign country leads to a decrease in output in the home country.

This is of course a very stylized model, and one can think of alternative policy instrumentsmost obviously fiscal policy - that may help sustain domestic demand in the home country. However, this policy strategy may not be viable if there is a need for fiscal policy adjustment to ensure debt sustainability.

Figure 1. Equilibrium Exchange Rate and Interest rate

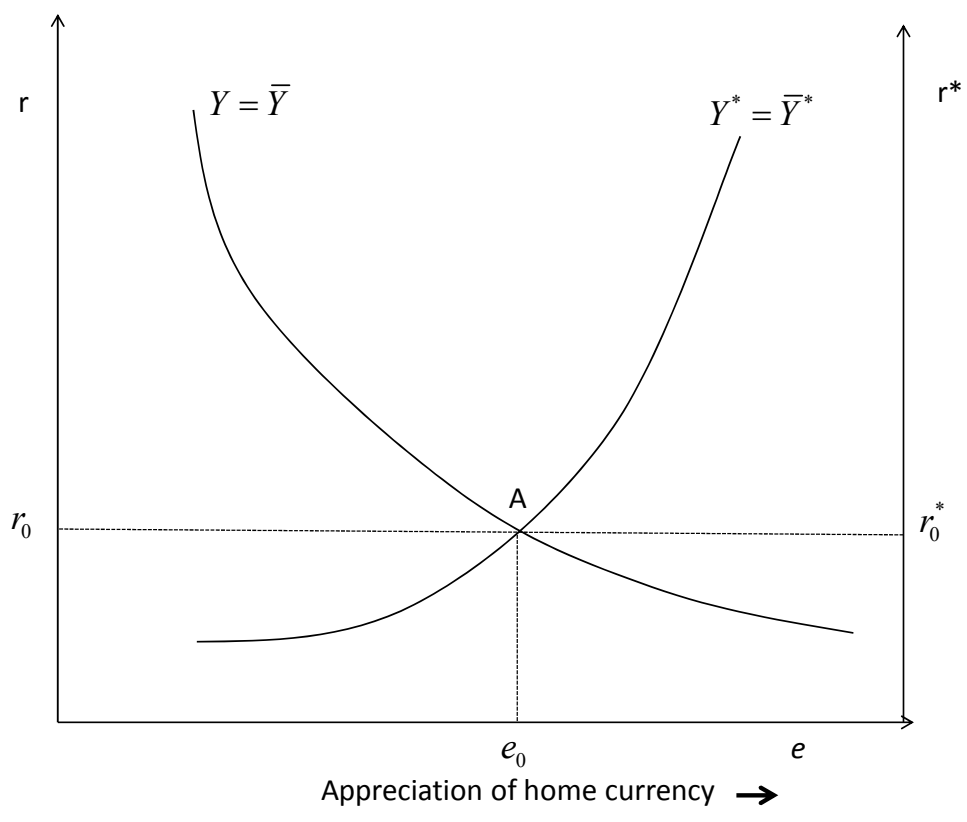


Figure 2. Impact of an Increase in Desired Foreign Saving

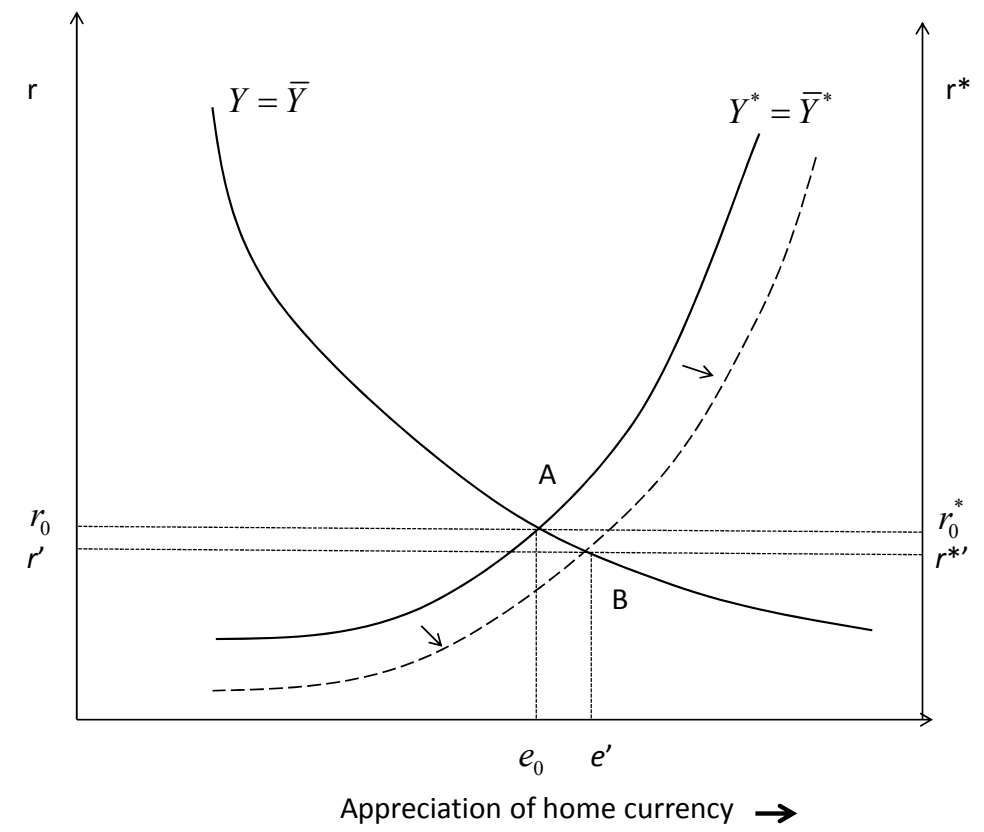

Figure 3. Increase in Foreign Saving, Zero Bound on Interest Rates

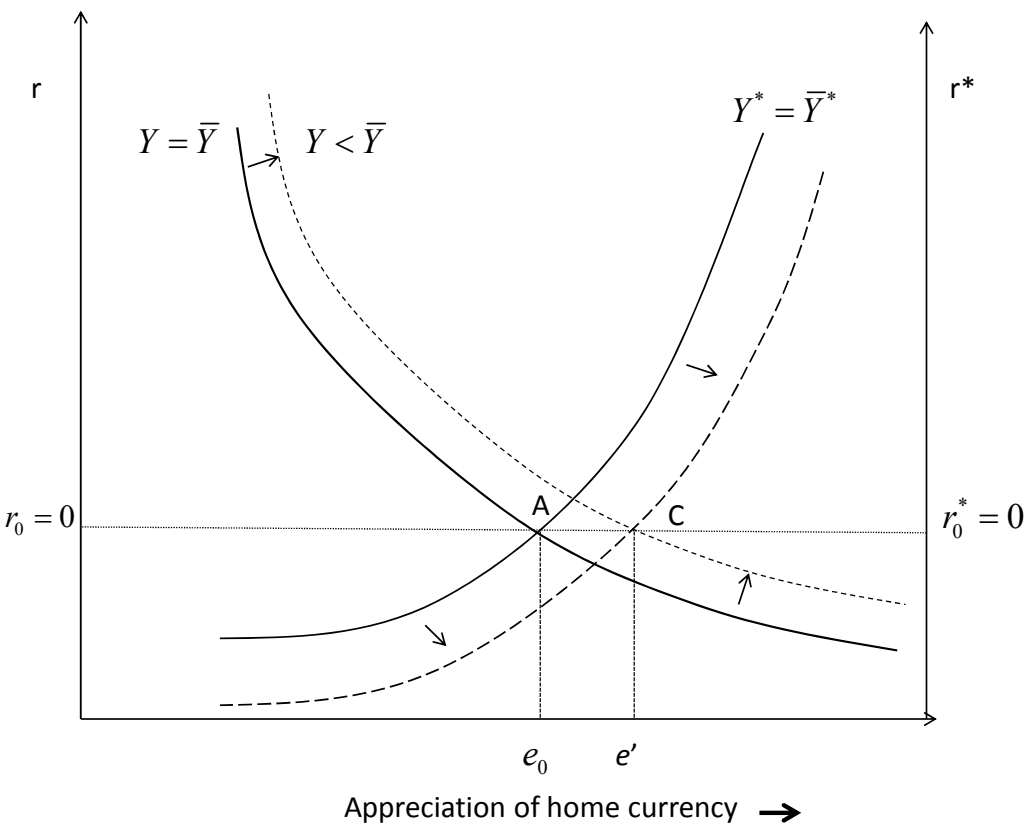

